\title{
Grain yield, yield components and protein content of organic spelt wheat (Triticum spelta L.) grown in different agro-ecological conditions of northern Serbia
}

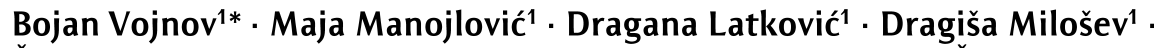 \\ Željko Dolijanović ${ }^{\cdot}$ Milena Simić ${ }^{3} \cdot$ Brankica Babec $^{4} \cdot$ Srđan Šeremešić $^{1}$
}

${ }^{1}$ University of Novi Sad, Faculty of Agriculture, Dositeja Obradvića Sq 8, 21000 Novi Sad, Serbia 'University of Belgrade, Faculty of Agriculture, Nemanjina 6, 11080, Belgrade-Zemun, Serbia ${ }^{3}$ Maize Research Institute "Zemun polje", Slobodana Bajića 1, 11185 Belgrade-Zemun, Serbia ${ }^{4}$ Institute of Field and Vegetable Crops, Maksima Gorkog 30, 21000 Novi Sad, Serbia

\begin{abstract}
Summary: Spelt wheat (Triticum spelta L.) is regarded as a crop with high nutritional properties. Cultivar Nirvana was analyzed on nine locations in semiarid conditions of northern Serbia in order to assess the effects of different agroecological conditions on the organic spelt wheat production, grain yield and yield components, as well as the quality of the spelt wheat. The highest dehulled grain yield was obtained in Nadalj organic farm (3.98 $\left.\mathrm{t} \mathrm{ha}^{-1}\right)$ on a carbonated chernozem, and the highest protein content in whole grain flour was found in organic spelt wheat from Pančevo $(13.94 \%)$. Correlation analysis showed significant positive correlations among grain yield, spike length, spike weight, number of grains per spike, 1000-grain weight and harvest index and among plant height, spike length, weight spike, and grain weight per spike. Our study indicated that growing spelt wheat in northern Serbia could result in higher grain yield, but protein content depended on crop management on each location.

Key words: grain yield, organic agriculture, protein content, spelt wheat
\end{abstract}

\section{Introduction}

Spelt wheat (Triticum spelta L.) is one of the most important alternative small grains, and is characterized by good adaptability and favorable qualitative attributes as compared with the common wheat (Triticum aestivum L.). According to Nesbitt (2001), spelt wheat origin can be traced back 7000 years ago in the Transcaucasia area. Koutroubas et al. (2012) indicated that the spelt wheat was important staple food in ancient Europe, and was afterwards the main type of wheat until the beginning of the $20^{\text {th }}$ century (Ruibal-Mendieta, 2002). However, the

Corresponding author:

bojan.vojnov@polj.uns.ac.rs

Acknowledgments:

This study is a part of the project TR 31072 "Status, trends and possibilities to increase the fertility of agricultural land in the Vojvodina Province" financed by the Ministry of Education, Science and Technological Development of the Republic of Serbia.

Cite this article:

Vojnov B., Manojlović M., Latković D., Milošev D., Dolijanović Ž., Simić M., Babec B., Šeremešić S. (2020). Grain yield, yield components and protein content of organic spelt wheat (Triticum spelta L.) grown in different agro-ecological conditions of northern Serbia. Ratar. Povrt., 57 (1), 1-7. gradual expansion of common wheat resulted in replacement of spelt wheat. The course of spelt wheat suppression by high yielding wheat varieties lasted until the end of $20^{\text {th }}$ century. Disadvantages in spelt wheat production, such as high percentage of glumes, complicated harvest and yields lower than in common wheat, resulted in its lower adoption (Nikolić et al., 2015). Additionally, spelt wheat hull is tightly attached to the grain and cannot be easily removed so the grain can be used for human consumption (Glamočlija et. al., 2004; Ugrenović et al., 2013). According to Šeremešić et al. (2017), organic production system is the most important system of sustainable agriculture. In highlydeveloped countries there is a modern model of food market. Those markets are quality-oriented, because of a choosey consumer who wants better quality of food (Roljević et al., 2018). Consumer awareness of the significance of food safety and the benefits of organic production has led to an increasing demand for alternative crops, among which the spelt wheat takes an important place. According to Ministry of Agriculture, Forestry and Water Management of the Republic of Serbia, spelt wheat is cultivated on the area of 157.9 ha and the greatest areas are in Vojvodina (120.04 ha) (Golijan et al., 2019). It is considered that spelt wheat 
has low requirements in terms of agro-ecological conditions, it is suitable for growing without pesticide use, and can be cultivated in marginal production areas compared to common wheat (Bonafaccia et al., 2000; Bavec and Bavec, 2006). According to Janković et al. (2013), the highest yields of the spelt wheat can be achieved on chernozem soil type, but due to its lower requirements it is often produced under restricted agroecological conditions. Earlier studies indicated that the sowing date played a significant role in higher yield achievement since late sowing caused shortening of the growing period and poor preparation of crops for the winter period (Protić et al., 2008). In a three-year trial, Ugrenović (2013) determined the highest spelt wheat yield in the first sowing date (October 5), while with sowing delay yield decreased from $4.0 \%$ to $19.7 \%$. Lacko-Bartošová et al. (2010) also found high variation in spelt wheat yield depending on climatic conditions. Spelt wheat has fewer requirements in terms of agroecological conditions, but is also less tolerant to drought (Ugrenović, 2013). In the dry seasons, yields are significantly lower, primarily due to a lack of nutrient availability under low fertilization. According to Dolijanović et al. (2012), the highest grain yields of spelt wheat were obtained by a combination of organic and microbial fertilizers $\left(5.84 \mathrm{t} \mathrm{ha}^{-1}\right)$, lower grain yield with a microbiological fertilizer $\left(4.34 \mathrm{t} \mathrm{ha}^{-1}\right)$, while the treatment without fertilizer resulted in the lowest yield (3.86 $\left.\mathrm{t} \mathrm{ha}^{-1}\right)$. However, complexity of the local agroecological conditions indicated that there is no unique solution to exploit the genetic potential of the variety (Ugrenović, 2018). On average, the quality of spelt wheat grain compared to the common wheat is higher regarding the total protein content (about 19\%), essential amino acids, B vitamins, lipids and mineral salts (Glamočlija et al., 2013). Given that the agroecological conditions of northern Serbia are strongly influenced by climatic changes and extreme weather events, obtaining higher yields while maintaining spelt wheat quality becomes a challenging task. The aim of this study was to determine the correlations among yield, yield components and protein content in spelt wheat for different sowing dates and applied management practices. Also, this study intended to determine the suitability of the soils at different locations for organic spelt wheat production in order to further improve production technology.

\section{Material and Methods}

In this study, spelt wheat was tested on nine different organic certified locations in northern Serbia in 2015/2016 (Table 1). The soil type belongs to the class of chernozems and humogley according to the WRB classification (2014) (Table 1). Samples of soils were collected from the topsoil $(0-30 \mathrm{~cm})$. The soil $\mathrm{pH}$ was determined in a soil:water suspension (1:2.5). The humus content was obtained by Tyurin titrimetric wet combustion method. The total $\mathrm{N}$ content was measured using Elementar CNS automatic analyzer. The available $\mathrm{P}_{2} \mathrm{O}_{5}$ and $\mathrm{K}_{2} \mathrm{O}$ content was measured by the Ammonium-Lactate (AL) method. Cultivar Nirvana developed at the Institute of Field and Vegetable Crops in Novi Sad was analyzed as the only Serbian spelt wheat cultivar. Crops were sown on different sowing dates (Table 1). The primary tillage was performed by plowing $(25 \mathrm{~cm})$ on all locations except in Pančevo and Zemun polje, where chizel plow $(15 \mathrm{~cm})$ and disc harrow $(15 \mathrm{~cm})$ were used, respectively. Regarding fertilization, organic farmers mostly used animal organic manure two or three years before sowing spelt wheat. The crops were sown in the optimal sowing period from October 5 to October 28, except for Zemun polje where crops were sown on November 13.

Table 1. Type of soils and crop management practices

\begin{tabular}{|c|c|c|c|c|c|}
\hline Location & Type of soil & Preceding crop & Fertilization & Tillage, depth & $\begin{array}{l}\text { Date of } \\
\text { sowing }\end{array}$ \\
\hline Ljutovo & Chernozem & Sunflower & Organic manure & Plow, $25 \mathrm{~cm}$ & Oct. 20 \\
\hline Orom & Humogley & Flax & Plowing crop remains & Plow, $25 \mathrm{~cm}$ & Oct. 27 \\
\hline Bajmok & Chernozem & Soybean & Organic manure & Plow, $25 \mathrm{~cm}$ & Oct. 25 \\
\hline Bački Petrovac & Chernozem & Soybean & $\begin{array}{l}\text { Pelletized organic manure } \\
\text { DIX 10N 500kg ha-1 }\end{array}$ & Plow, $25 \mathrm{~cm}$ & Oct. 15 \\
\hline Nadalj & Chernozem & Soybean & $\begin{array}{l}\text { Pelletized organic manure } \\
\text { DIX 10N } 500 \mathrm{~kg} \mathrm{ha}^{-1}\end{array}$ & Plow, $25 \mathrm{~cm}$ & Oct. 20 \\
\hline Crepaja & Humogley & Maize & Organic manure & Plow, $25 \mathrm{~cm}$ & Oct. 14 \\
\hline Pančevo & Chernozem & Soybean & Plowing crop remains & Chisel plow, $15 \mathrm{~cm}$ & Oct. 5 \\
\hline Zemun polje & Chernozem & Maize & $\begin{array}{l}\text { Pelletized organic manure DIX } \\
10 \mathrm{~N} 500 \mathrm{~kg} \mathrm{ha}^{-1}\end{array}$ & Disc harrow, $15 \mathrm{~cm}$ & Nov. 13 \\
\hline Radmilovac & Chernozem & Maize & Organic manure & Plow, $25 \mathrm{~cm}$ & Oct. 28 \\
\hline
\end{tabular}




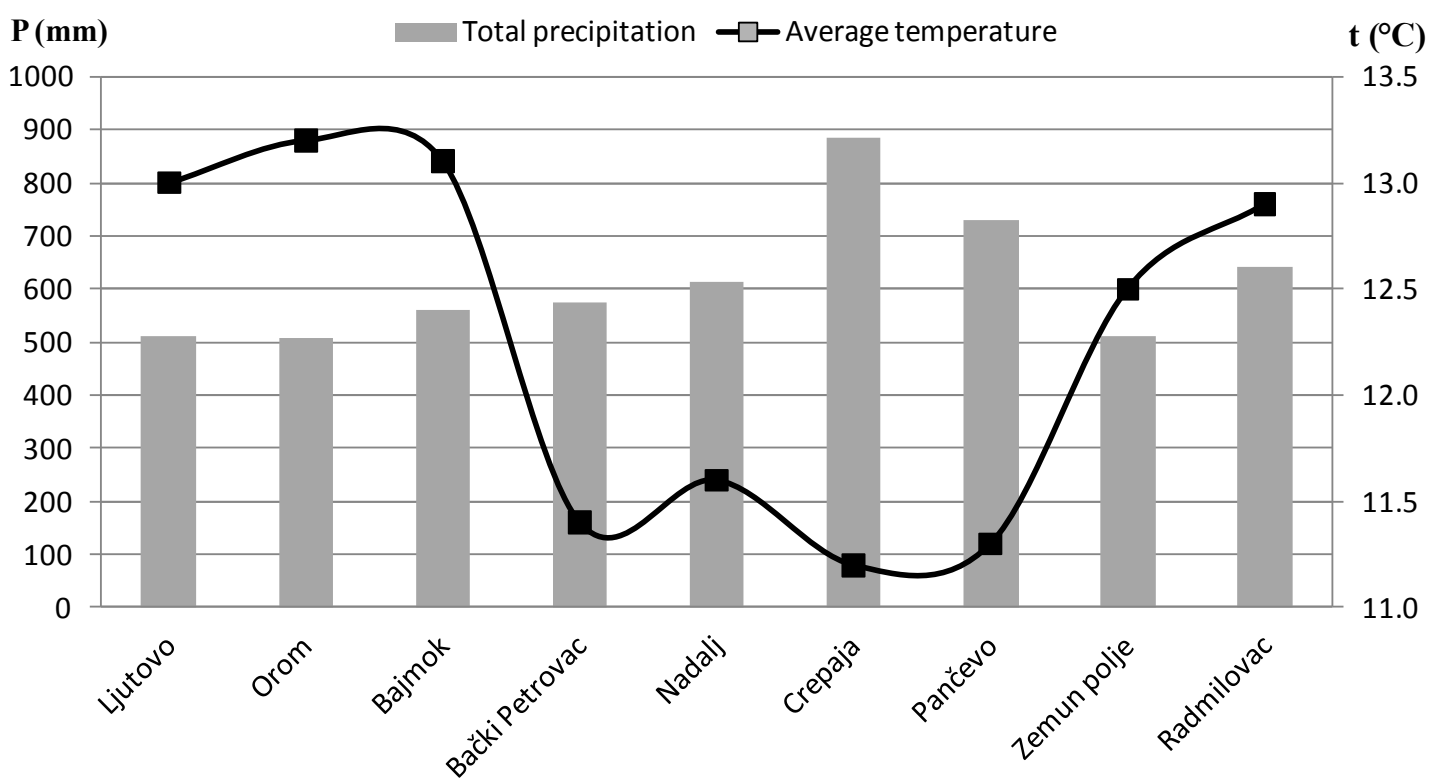

Figure 1. Total precipitation and average temperatures from October 2015 to July 2016

The meteorological data were retrieved from different weather stations near the trial locations in Vojvodina and Belgrade. Basic climate characteristics (average temperature and precipitation) for the period from October 2015 to July 2016 are shown in Figure 1. The lowest average monthly temperatures were recorded in January $\left(-0.3{ }^{\circ} \mathrm{C}\right)$ in Crepaja and Ljutovo, while the highest monthly temperatures were recorded in July in Orom at the end of the growing period (23.1 $\left.{ }^{\circ} \mathrm{C}\right)$. Precipitation greatly varied across the study area. Higher precipitation was recorded in this growing season compared to the long-term average values for Vojvodina. The highest precipitation sum was recorded in Crepaja $(886.1 \mathrm{~mm})$, while the lowest was recorded in Orom (506 mm) (Figure 1.).

The comparisons of the basic agrochemical properties of the soil on selected locations are shown in Table 2. Analyses of agronomic traits, such as number of plants, plant height, spike length, spike weight, number of grains per spike, grain weight per spike, 1000 -grain weight, harvest index and dehulled grain yield, were performed manually on samples of 10 plants in five replications. Determination of protein content in the whole grain meal was performed by the Carbon, Hydrogen, Nitrogen and Sulphur (CHNS) method, on Vario EL III elemental analyzer. The analysis of variance (ANOVA) was used to test differences among the locations for grain yield and protein content, followed by a Fisher's LSD test $(\mathrm{P}<0.05)$. Correlation analysis of the analyzed traits and the principal component analysis (PCA), used to visualize relationships between the traits and the locations were performed using STATISTICA 12.6, StatSoft, Inc.

\section{Results and Discussion}

The highest humus content $(4.02 \%)$ was recorded on the organic field in Nadalj, which belongs to the soil class rich in humus (Table 2). Higher humus content was also found in Oromo, Bajmok, Crepaja, Nadalj and Pančevo organic fields, ranging from $3.38 \%$ to $4.02 \%$. Lower humus contents were identified in Ljutovo, Bački Petrovac, Zemun Polje and Radmilovac, (from $2.14 \%$ to $2.50 \%$ ). The obtained values of humus content were in accordance with the findings of Manojlović et al. (2008) that the optimal to high soil fertility was necessary for successful organic production in Vojvodina. Regarding total nitrogen content $(\mathrm{N} \%)$, Orom, Bajmok, Nadalj, Crepaja and Pančevo were characterized with high total $\mathrm{N}$ content $(0.2 \%-0.3 \%)$, whereas moderately high content of total nitrogen $(0.1 \%-0.2 \%)$ was found in other locations. In addition, soil samples from different locations had optimal (15$25 \mathrm{mg} / 100 \mathrm{~g})$ to high (25-50 mg/100g) phosphorus and potassium contents. Considering values of soil chemical properties, increasing soil fertility could be a key prerequisite for sustainable organic production (Manojlović et al., 2008).

The highest yield of dehulled grains of spelt wheat was determined in Nadalj (3.98 $\mathrm{t} \mathrm{ha}^{-1}$ ) and Pančevo (3.68 $\mathrm{t} \mathrm{ha}^{-1}$ ) on carbonate chernozem (Figure 2.), with an optimal sowing period. These findings demonstrated that high soil organic matter content could be associated with higher yields. Compared with other locations, such as Orom and Bajmok, Nadalj and Pančevo had better soil texture reflected in high soil fertility. Also, significant yields were determined in 
Table 2. Agrochemical soil properties of investigated locations

\begin{tabular}{|c|c|c|c|c|c|c|c|c|}
\hline \multirow{2}{*}{ Locations } & \multirow{2}{*}{ Type of soil } & \multicolumn{2}{|c|}{$\mathrm{pH}$} & \multirow{2}{*}{$\begin{array}{c}\mathrm{CaCO}_{3} \\
\%\end{array}$} & \multirow{2}{*}{$\begin{array}{l}\text { Humus } \\
\%\end{array}$} & \multirow{2}{*}{$\begin{array}{c}\text { Total } \mathrm{N} \\
\%\end{array}$} & \multirow{2}{*}{$\mathrm{P}_{2} \mathrm{O}_{5}$} & \multirow{2}{*}{$\mathrm{K}_{2} \mathrm{O}$} \\
\hline & & $\mathrm{KCl}$ & $\mathrm{H}_{2} \mathrm{O}$ & & & & & \\
\hline Ljutovo & Chernozem & 7.56 & 8.18 & 4.20 & 2.51 & 0.187 & 17.7 & 20.5 \\
\hline Orom & Humogley & 7.53 & 8.24 & 15.12 & 3.66 & 0.251 & 17.0 & 17.3 \\
\hline Bajmok & Chernozem & 7.41 & 8.21 & 12.60 & 3.63 & 0.249 & 19.3 & 19.1 \\
\hline Bački Petrovac & Chernozem & 7.09 & 7.98 & 1.60 & 2.46 & 0.183 & 26.1 & 30.0 \\
\hline Nadalj & Chernozem & 7.32 & 8.10 & 6.72 & 4.02 & 0.258 & 20.8 & 29.1 \\
\hline Crepaja & Humogley & 7.44 & 8.26 & 18.48 & 3.38 & 0.232 & 36.3 & 54.5 \\
\hline Pančevo & Chernozem & 7.35 & 8.18 & 13.02 & 3.56 & 0.244 & 27.9 & 20.0 \\
\hline Zemun polje & Chernozem & 7.30 & 8.21 & 8.40 & 2.50 & 0.186 & 34.2 & 28.2 \\
\hline Radmilovac & Chernozem & 7.10 & 8.13 & 1.40 & 2.15 & 0.160 & 17.9 & 21.4 \\
\hline Average & & 7.36 & 8.13 & 9.54 & 3.15 & 0.220 & 23.9 & 26.3 \\
\hline
\end{tabular}

Crepaja (3.57 $\mathrm{t} \mathrm{ha}^{-1}$ ) with the optimal sowing date (October 14). It should be noted that sufficient precipitation was recorded in these locations during the growing season compared to the long-term average, which presumably led to such high yields. Significantly lower yield was determined in Ljutovo in the north of Vojvodina (3.02 $\left.\mathrm{t} \mathrm{ha}^{-1}\right)$. These yield differences could be a consequence of higher temperatures in critical periods of the grain filling of spelt wheat, as well as of lower rainfall, with a slightly unfavorable distribution in Ljutovo, than in the locations with the highest yields. Grain yield in wheat can be influenced by many factors such as weather conditions, management practices, and the availability of nutrients. According to Jankovic et al. (2013), the highest yields of cereals can be achieved on chernozem, and the diversity of agro-ecological conditions could influence the yield of the same variety of cereals. Jevtic (1992) elaborated that the highest yields and best quality could be achieved in regions with total rainfall from 650 to $750 \mathrm{~mm}$, but distributed according to the crop requirements specific for each developmental stage.
Grain protein content is considered as important quality trait in spelt wheat (Auerman, 1988). The protein content of spelt wheat grains is far greater than the protein content of common wheat (Petrenko et al., 2018). The highest protein content was measured in Pančevo (13.94\%), and the lowest in Zemun polje experimental station (10.5\%) (Figure 3.). BodrozaSolarov et al. (2010) determined higher values of the protein content $(16.8 \%)$ of the same spelt wheat cultivar Nirvana under conventional production conditions in Bačka Topola, while the percentage of protein in common wheat was similar to protein content of spelt wheat obtained in our study $(13.2 \%)$. Ikanović et al. (2016) found that climate factors, such as temperature and light intensity, and the period of the grain filling had a significant impact on the protein content of the grain of spelt wheat. In the same study, the protein content of the Nirvana variety was found to be $16.67 \%$. It is also stated that the highest protein content was found in spelt wheat grown on chernozem soil. The protein content in our study was calculated on the sample base because only one cultivar was analyzed.

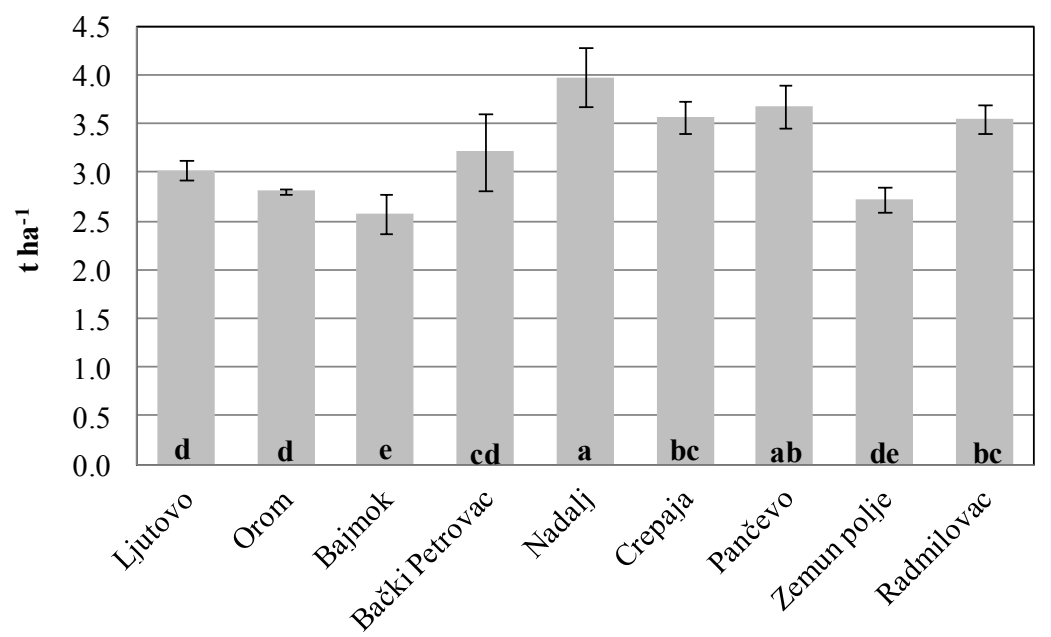

Figure 2. Yield of dehulled grain spelt wheat

Letters (abcde) indicate statistically significant differences of yield between locations based on the Fisher test 


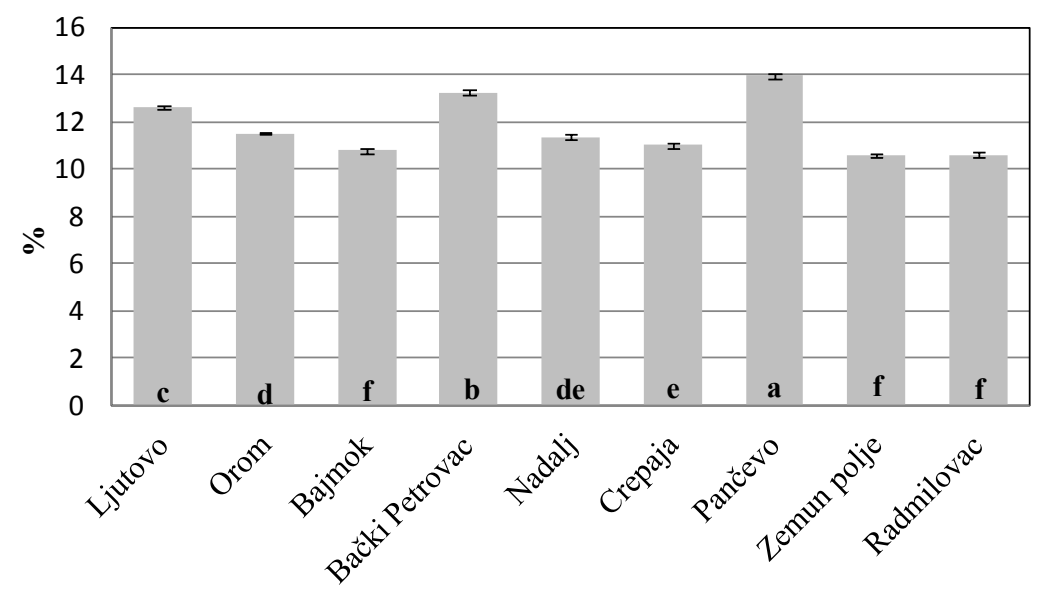

Figure 3. Protein content of integral spelt wheat flour

Letters (abcdef) indicate statistically significant differences of protein content of grain spelt wheat between locations based on the Fisher test

In addition, the weather conditions in 2016 were suitable for spelt wheat cultivation, resulting in higher grain yield. The protein content was lower than in the study of Bodroža Solarav et al. (2010) with long spring drought. Also, our study showed that location with the highest yield in Nadalj did not have high protein content of the integral flour, which is in accordance with a positive but not significant correlation between the yield and protein content $(r=0.354, \mathrm{P}<0.258)$. This could probably be due to a high climatic contribution on spelt wheat growth and diverse locations.

In our study, there were significant positive correlations between plant height and spike length $(\mathrm{r}=0.65, \mathrm{p}<0.05)$, and between plant height and spike weight $(r=0.63, p<0.05)$ (Table 3). Spike weight was positively correlated $(\mathrm{p}<0.01)$ with the number of grains per spike and grain weight per spike. Significant positive correlations between the grain yield and the spike length $(r=0.70, p<0.01)$, spike weight $(r=0.70$, $\mathrm{p}<0.01)$, the number of grains per spike $(\mathrm{r}=0.71$, $\mathrm{p}<0.01), 1000$-grain weight $(\mathrm{r}=0.59, \mathrm{p}<0.05)$, and the harvest index $(\mathrm{r}=0.67, \mathrm{p}<0.05)$ were also determined. The significant positive correlations among plant height, spike length, spike weight, and grain weight per spike were similar to the results of Jankovic et al. (2015). Significant positive correlations between spike length and spike weight, and between number of grains per spike and grain weight per spike $(p<0.01)$ were in line with Xie et al. (2015). According to Hristov et al. (2008), winter wheat yield was found to be dependent on several major yield components, such as number of plants or spike per unit area, number of grains per spike, and grain weight per spike. There are complex interrelationships between these traits, as increasing the value of one often results in a decrease in the value of another. Better understanding of relationship among the traits and their interdependence could facilitate yield improvement per unit area (Jankovic et al., 2015). This indicates that the appropriate management practices applied in the production of spelt wheat, by improving the yield components, could significantly increase grain yield.

Table 3. Correlation analysis of different properties of spelt wheat

\begin{tabular}{|c|c|c|c|c|c|c|c|c|c|}
\hline & SL & SW & NGS & GW & GI & GW 1000 & HI & DGY & $\mathrm{P}$ \\
\hline $\mathrm{PH}$ & $0.65^{*}$ & $0.63^{*}$ & 0.47 & $0.68^{* *}$ & 0.01 & 0.17 & -0.05 & 0.55 & 0.26 \\
\hline SL & 1.00 & $0.91 * *$ & $0.86^{* *}$ & $0.85^{* *}$ & -0.15 & 0.46 & 0.12 & $0.70 * *$ & $0.59 *$ \\
\hline SW & & 1.00 & $0.85^{* *}$ & $0.96^{* *}$ & -0.30 & $0.60^{*}$ & 0.16 & $0.70^{* *}$ & 0.30 \\
\hline NGS & & & 1.00 & $0.77 * *$ & -0.48 & 0.49 & 0.25 & $0.71 * *$ & 0.37 \\
\hline GW & & & & 1.00 & -0.37 & $0.58^{*}$ & 0.23 & $0.71^{* *}$ & 0.29 \\
\hline GI & & & & & 1.00 & -0.42 & -0.36 & -0.36 & 0.06 \\
\hline GW 1000 & & & & & & 1.00 & 0.38 & $0.59 *$ & 0.38 \\
\hline $\mathrm{HI}$ & & & & & & & 1.00 & $0.67^{*}$ & -0.01 \\
\hline DGY & & & & & & & & 1.00 & 0.35 \\
\hline $\mathrm{P}$ & & & & & & & & & 1.00 \\
\hline
\end{tabular}

PH - Plant height; SL -Spike length; SW - Spike weight; NGS - Number of grains per spike; GW - Grain weight per spike; GI - Glume index; GW 1000 -1000 Grains weight; HI - Harvest index; DGY - Dehulled grain yield; P - Protein content; *,** significant at probability level of $\mathrm{p}<0.05$ and $\mathrm{p}<0.01$, respectively. 


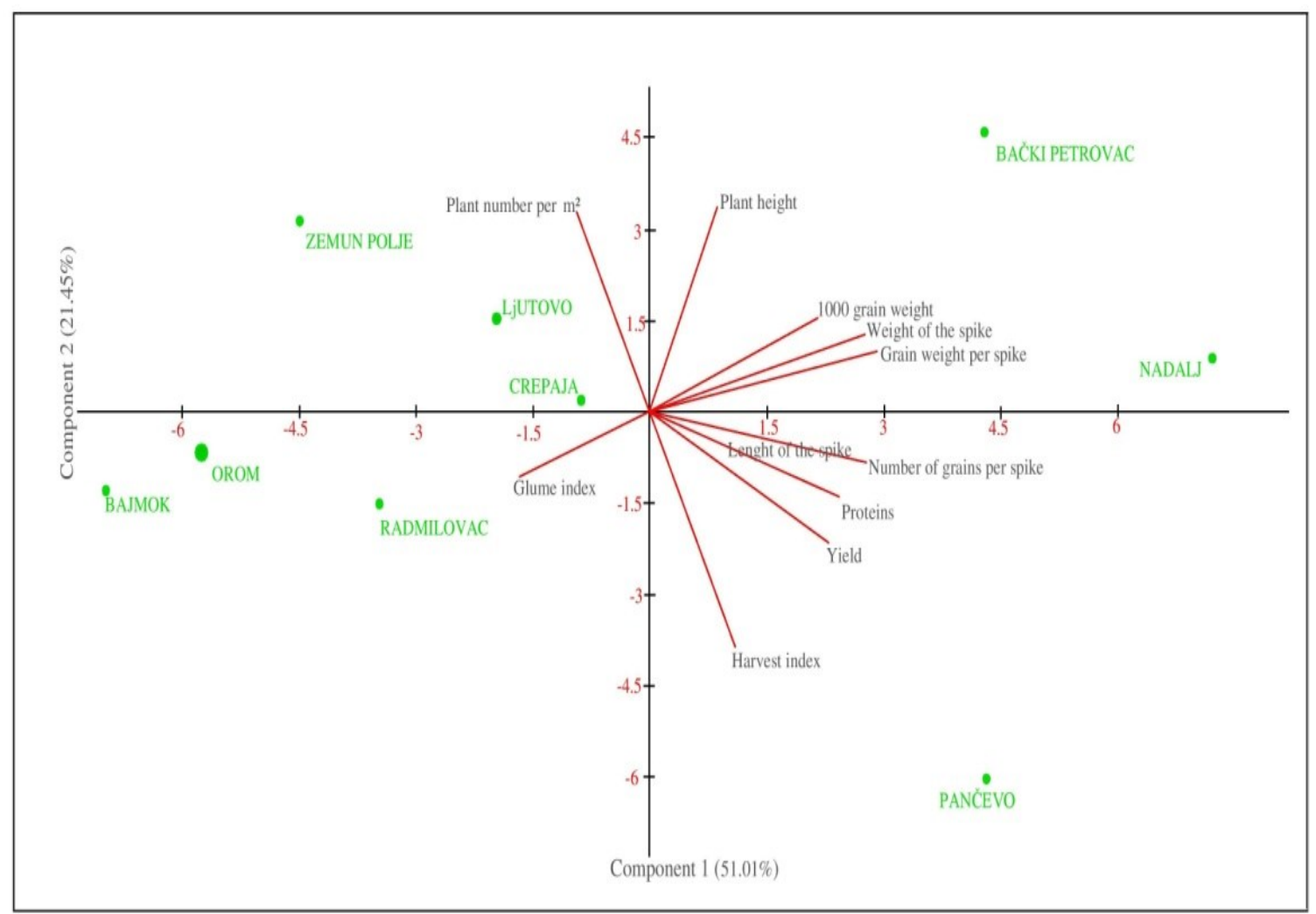

Figure 4. PCA biplot of spelt wheat traits across nine locations

The obtained data were analyzed with PCA to allow for correlations to be observed in the space of the components which are available, i.e. in the space of spelt wheat parameters collected during the trial. The PCA was performed to have a better understanding about the relationships of the yield components and the investigated locations. The PC biplot reflected $72.46 \%$ of the variations, corresponding to $51.01 \%$ (PC 1) and $21.45 \%$ (PC 2) (Figure 4.). Arrangement of locations and grain characteristics revealed that the location with the highest yield (Nadalj) is associated with most traits including yield and protein content compared to the locations with lower yields (Bajmok and Orom). This implies that all traits must be considered in order to improve spelt wheat production.

\section{Conclusion}

The highest spelt wheat yield of $3.98 \mathrm{t} \mathrm{ha}^{-1}$ was observed at Nadalj, the location on carbonate chernozem with the highest level of humus and an optimal sowing time. Significant positive correlations were determined between grain yield and spike length, spike weight, number of grains per spike, grain weight per spike, 1000-grain weight and harvest index. The principal component analysis showed that locations with higher yields (Nadalj and Pančevo) were positioned around vectors for yield and most yield components, corroborating their positive correlations and implying that all traits must be considered in order to improve spelt wheat production. Our study indicated that spelt wheat growing in northern Serbia could achieve high yields, but protein content seems to depend more on the production technology. Therefore, the future research should focus on specific management practices and their effects on yield and quality of spelt wheat.

\section{References}

Auerman, L. J. (1988). Tehnologija pekarske proizvodnje (Breadmaking Technology). University of Novi Sad, Faculty of Technology, Novi Sad.

Bavec, F., Bavec, M. (2006). Organic production and use of alternative crops. CRC Press. Bodroza-Solarov, M., Balaz F., Bagi, F., Filipcev, B., Simurina, O., Mastilovic, J.(2010). Effect of hulls on grain mould infestation in Triticum aestivum ssp. spelta from organic trial. $45^{\text {th }}$ Croatian \& 5 th International Symposium on Agriculture, Agroecology and Ecological Agriculture, 15-19 February 2010, Opatija, Croatia, 51-54.

Bonafaccia, G., Galli, V., Francisci, R., Mair, V., Skrabanja, V., Kreft, I. (2000). Characteristics of spelt wheat products and nutritional value of spelt wheat-based bread. Food Chemistry, 68(4), 437-441.

Dolijanović, Z., Oljača, S., Kovačević, D., Jug, I., Stipešević, B., Poštić, D. (2012). Utjecaj agrotehničkih mjera na prinos zrna pira (Triticum aestivum spp. spelta) u organskom sustavu uzgoja (The effect of cultivation practices on spelt wheat grain yield in organic farming). Proceedings 47th Croatian and 7 th International Symposium on Agriculture. Opatija. Croatia (51)1.55.

Glamočlija, Đ. (2004). Posebno ratarstvo, žita $i$ zrnene mahunarke (Special field crops, grains and grain legumes). Draganić, Beograd.

Glamočlija, Đ., Žarković, B., Dražić, S., Radovanović, V., Popović, V., Ugrenović, V., Zekić N. (2013). Morfološke i produktivne osobine pšenice krupnika na černozemu i degradiranom 
zemljištu (Morphological and production traits of spelt wheat on chernozem and degraded soils). Zbornik naucnih radova sa XXVII Savetovanja agronoma, veterinara, tehnologa $i$ agroekonomista, Institut PKB Agroekonomik. (19)1-2. 23-30.

Golijan, J., Kolarić, L., Popović, A., Živanović, L. (2019). Proizvodnja organskog krupnika (Triticum spelta L.) u Srbiji (Production of organic spelt wheat in Serbia). Selekcija i semenarstvo, 25(1), 23-32.

Hristov, N., Mladenov, N., Kondić-Špika, A., Štatkić, S., Kovačević, N. (2008). Direct and indirect effects of several wheat traits on grain yield. Zbornik radova Instituta za ratarstvo i pourtarstvo, 45(2), 15 -20 .

Ikanović, J., Popović, V., Janković, S., Dražić, G., Živanović, L., Lakić, Ž., Savić, J. (2016). Productivity of hexaploid spelt wheat Triticum aestivum spp. spelt grown on degraded soil. VII International Scientific Agriculture Symposium," Agrosym 2016", 6-9 October 2016, Jahorina, Bosnia and Herzegovina. 996-1004.

IUSS Working Group WRB (2014). World Reference Base for Soil Resources 2014. International soil classification system for naming soils and creating legends for soil maps. World Soil Resources Reports 106. FAO, Rome.

Janković, S., Ikanović, J., Popović, V., Rakić, S., Kuzevski, J. (2013). Agro-ecological conditions and morphoproductive properties of spelt wheat. Biotechnology in Animal Husbandry, 29(3), 547-554.

Jankovic, S., Ikanovic, J., Popovic, V., Rakic, S., Pavlovic, S., Ugrenovic, V., Doncic, D. (2015). Morphological and productive traits of spelt wheat - Triticum spelta L. Poljoprivreda i Sumarstvo, 61 (2), 173.

Jevtić, S. L. (1996). Přsenica (Wheat). Beograd: Nauka.

Koutroubas, S. D., Fotiadis, S., Damalas, C. A. (2012). Biomass and nitrogen accumulation and translocation in spelt (Triticum spelta) grown in a Mediterranean area. Field Crops Research, 127, 1-8.

Lacko-Bartošová, M., Korczyk-Szabó, J., Ražný, R. (2010). Triticum Spelta - a specialty grain for ecological farming systems. Research Journal of Agricultural Science. 42(1): 143-147.

Manojlović, M. (2008). Plodnost zemljišta u organskoj proizvodnji u Vojvodini (Soil fertility in organic farming in Vojvodina). Đubrenje u održivoj poljoprivredi. Poljoprivredni fakultet, Novi Sad

Nesbitt, M. (2001). Wheat evolution: integrating archaeological and biological evidence. Wheat taxonomy: the legacy of John Percival, edited by P. D. S.Caligari and P. E. Brandham. London: Linnean Society, Linnean Special Issue 3, 37-39.

Nikolić, O, Pavlović, M, Savurdić, A., Jelić, M. (2015). Mogućnosti gajenja spelte u organskoj poljoprivredi (Possibilities of growing spelt wheat in organic farming). XX Savetovanje o biotehnologiji. Zbornik radova, 20(22). 117-122.

Petrenko, V., Sheiko, T., Khudolii, L., Bondar, V. (2018). Evaluation of three wheat species commonly used in organic cropping systems, considering selected technological parameters for ethanol production. In proceedings of the international scientific conference. Engineering for rural development, 23.-25 May 2018, Jelgava, 451-456.

Protić, R., M. Marković i N. Protić (2008): Prinos zrna ozime pšenice u jednoj sušnoj godini u Republici Srbiji (Winter wheat grain yield in a dry year in Serbia). Poljoprivredne aktuelnosti, 7(1-2), 5-19.

Roljević, S., Sarić, R., Kuzman, B. (2018). Significance in innovation and knowledge appliance in system of organic agriculture in Serbia. Economics of Agriculture, 57, 247-254.

Ruibal-Mendieta, N. L., Delacroix, D. L., Muerens, M. (2002). A comparative analysis of free, bound and total lipid content on spelt and winter wheat wholemeal. Journal of Cereal Science, 35, 337 -342 .

Šeremešić, S., Vojnov, B., Manojlović, M., Milošev, D., Ugrenović, V., Filipović, V., Babec, B. (2017). Organska poljoprivreda u službi biodiverziteta i zdravlja (Organic farming for biodiversity and health). Letopis naucnih radova. University of Novi Sad, Faculty of Agriculture, 41(2), 51-60.

Ugrenović, V. (2013). Uticaj vremena setve i gustine useva na ontogenezu, prinos $i$ kvalitet zrna krupnika (Triticum spelta L.) (The effect of planting date and crop density on the ontogenesis, yield and grain quality of spelt wheat). Doctoral dissertation. University of Belgrade, Faculty of Agriculture.

Ugrenović, V., Bodroža Solarov, M., Pezo, L., Đisalov, J., Popović, V., Marić, B., Filipović, V. (2018). Analysis of spelt variability (Triticum spelta L.) grown in different conditions of Serbia by organic conditions. Genetika, 50(2), 635-646.

Xie, Q., Mayes, S., Sparkes, D. L. (2015). Spelt as a genetic resource for yield component improvement in bread wheat. Crop Science, 55(6), 2753-2765.

\section{Morfološke karakteristike, prinos i sadržaj proteina u zrnu krupnika (Triticum spelta L.) gajenog u organskom sistemu proizvodnje u različitim agroekološkim uslovima severnog dela Srbije}

\section{Bojan Vojnov · Maja Manojlović · Dragana Latković · Dragiša Milošev · Željko Dolijanović · Milena Simić · Brankica Babec · Srđan Šeremešić}

Sažetak: Zbog svojih nutritivnih osobina, krupnik (Triticum spelta L.) je sve više u interesovanju organskih proizvođača i potrošača. U cilju unapređenja organske proizvodnje i uvođenja alternativnih kultura, sprovedeno je istraživanje na ovoj vrsti pšenice kako bi se sagledao uticaj različitih agroekoloških uslova na prinos i komponente prinosa, kao i kvalitet krupnika. Predmet istraživanja bila je sorta krupnika Nirvana, a istraživanje je obavljeno na 9 različitih lokaliteta u Vojvodini i u okolini Beograda na kojima je krupnik gajen u sistemu organske proizvodnje. Najveći prinos oljuštenog zrna krupnika utvrđen je na organskoj parceli u Nadalju sa 3,98 t/ha na karbonatnom černozemu, a najveći sadržaj proteina $(13,94 \%)$ u integralnom brašnu sa organske parcele iz Pančeva. Korelaciona analiza je pokazala da na ispitivanim lokalitetima postoji statistički značajna korelacija između prinosa krupnika i dužine klasa, mase klasa, broja zrna, mase 1000 zrna i žetvenog indeksa, a takođe postoji uzajamni uticaj između visine biljaka, dužine klasa, mase klasa i mase zrna po klasu. Iako je krupnik relativno skromnih zahteva prema plodnosti zemljišta i podnosi nepotpunu agrotehniku, utvrđeno je da odlično reaguje na đubrenje stajnjakom sa produženim dejstvom i na intenzivniju agrotehniku pri kojoj se mogu postići prinosi i do $4 \mathrm{t} \mathrm{ha}^{-1}$ oljuštenog zrna. Najveći uticaj na prinos su imali vreme setve, raspored i količina padavina, kao i obezbeđenost biljaka potrebnim hranivima. Takođe, utvrđeno je da pravilna agrotehnika može da ublaži negativni uticaj nepovoljnih uslova spoljašnje sredine, što je uticalo da se na različitim lokalitetima ostvare visoki prinosi.

Ključne reči: krupnik, organska poljoprivreda, prinos zrna, sadržaj proteina 